\title{
"New York and yet not New York": Reading the Region in Contemporary Brooklyn Fictions
}

James Peacock

\section{(2) OpenEdition}

\section{Journals}

Electronic version

URL: https://journals.openedition.org/ejas/6403

DOI: $10.4000 /$ ejas.6403

ISSN: 1991-9336

Publisher

European Association for American Studies

\section{Electronic reference}

James Peacock, "'New York and yet not New York": Reading the Region in Contemporary Brooklyn Fictions", European journal of American studies [Online], 3-3। 2008, document 5, Online since 02 December 2008, connection on 08 July 2021. URL: http://journals.openedition.org/ejas/6403 ; DOI: https://doi.org/10.4000/ejas.6403

This text was automatically generated on 8 July 2021.

Creative Commons License 


\title{
"New York and yet not New York": Reading the Region in Contemporary Brooklyn Fictions
}

\author{
James Peacock
}

1 Is Brooklyn "the conscience of New York?" Jonathan Lethem believes so:

While Manhattan tears everything down and changes everything, Brooklyn does a similar thing, but fails miserably at it. It is a crazy quilt of a place. A mongrel place of sorts. It mixes old and modern in a haphazard way. It represents a tiny microcosm of the world-a functional utopia. There is also a weakness for nostalgia here, but it is a flinty and cold-eyed nostalgia. Brooklynites sort of have a built in shrug about nostalgia while still caring about it (Kushner 14).

Anthony LaSala's and Seth Kushner's project The Brooklynites, from which the quotation is taken, trades on the kinds of largely benign tensions Lethem identifies. From the two hundred or so interviews with Brooklyn citizens (ranging from fishermen to handball players, photographers to celebrity authors), there emerges a composite picture of a cohesive community, comprised nonetheless of quirky, unique individuals. Shabby, gentrified, friendly and dangerous, Brooklyn is a place where the neighbors will always chat with you and "your local baker [...] knows how many sugars you have in your coffee" (Kushner 106). It epitomizes the diversity Carrie Tirado Bramen argues has become axiomatic in almost all discussions of American identity (Bramen 5).

How regional identity is revealed through recent novels about Brooklyn is the subject of this article. From Hubert Selby Jr.'s Last Exit to Brooklyn (1964) to Paula Fox's Desperate Characters (1970) and latterly in Lethem's The Fortress of Solitude (2003), Brooklyn novels have always regarded the borough as "a crazy quilt of a place," even if, as in Desperate Characters, the main theme is bourgeoisification and the fear of difference. Lethem's metaphor again takes diversity as a given, but the reference to nostalgia implies the danger of that diversity itself becoming fossilized, undynamic, existing in situ as local color rather than as a part of continuing transcultural negotiations. As Philip Joseph observes in his recent book on literary regionalism, 
the history of regionalism has been suffused with longing for primeval communities, determined not by worldly subjects in dialogue with each other but by local traditions putatively rooted in land and in blood (10).

\section{live in an interconnected, nomadic world" (6). This is certainly the case; in fact, literary} regionalism has always dramatized, to varying extents, negotiations between the local and the global.

7 Where this article departs from Joseph is first in the choice of primary material. Regionalism is the starting point, but it will become clear that not all of the Brooklyn fictions dealt with are "regionalist" in any conventional sense, that is, combining romanticism and realism in a depiction of specific regions full of local detail and description. In fact, the more effective Brooklyn fictions depart from this model into more abstract, ethical territory. And while Joseph focuses on the present-day transformative potential of texts from the widely-studied period of literary regionalism in the late nineteenth and early twentieth centuries (by authors such as Hamlin Garland and Willa Cather), the primary interest here is in the contemporary. This is because it is in the late twentieth and early twenty-first centuries that terms like "community," "locality" or "region" are - for reasons connected with, amongst other things, global capital, global media, and the threat of terrorism - particularly hard to define and therefore consistently up for debate.

Zygmunt Bauman, for example, records a number of factors leading to a contemporary "devaluation of local opinions" and a degradation of regional community in his book Community (63). While acknowledging that there has always been a tension between freedom and security in community (20), he acknowledges that travel and informatics have further destabilized the notion by elevating "extraterritoriality." Extraterritorial individuals are mobile, liquid, global, cosmopolitan, yet have no interest in "a new global cultural synthesis" (55). Rather, their ideal is a private, individualistic aloofness, a secession from intimacy based on "a series of new beginnings" (53). Bauman attributes this "self-chosen exile" (52) quite specifically to consumerism. Another consequence is the "aesthetic community" which looks to celebrities for authority, and is as remote from a spirit of local community as the famous lives it aspires to (66). With such issues in mind, it is rewarding to explore how contemporary works of literature reflect changing notions of community, locality, and region. Do they celebrate the new extraterritoriality, or reassert conceptions of community based on land, family, tradition? How do they reconcile the fact that "large portions of the United States, from Tucson to Milwaukee and from Seattle to Tampa Bay, look and feel largely identical" (Kowalewski 12) with their evocations of regional distinctiveness? This article also departs from Philip Joseph's analysis, then, in assuming quite simply that there is more at stake and more of relevance to contemporary issues in looking at contemporary literary communities as a twenty-first-century reader. 
9 And although this is not an article about 9/11, the events of that day lie beneath its readings of Brooklyn fictions, and occasionally break the surface. With cities from New York to London to Rangoon so relentlessly portrayed in the media as sites of conflict, violence and tension between ethnic communities, there is urgency in defining the parameters and the culture of community against the backdrop of grand narratives of religion, global politics and war, narratives responsible in the final analysis for a tragedy like 9/11. Brooklyn, proud of both its globally representative population and its de-centered urban regional status, is an ideal test case. Paul Auster can say of his Brooklyn neighborhood, Park Slope, that

[e]veryone lives there, every race and religion and economic class, and everyone pretty much gets along. Given the climate in the country today, I would say that qualifies as a miracle (3 Films 18).

10 It is necessary to dig deeper into such sentiments, to filter them through literary portrayals and consider to what extent they represent a celebration of that miracle or a denial of wider ethical and socio-political factors.

11 So in what sense is Brooklyn "New York and yet not New York?" This description is taken from Paul Auster's Brooklyn Follies (2005). Clearly influenced by Blue in the Face, the ramshackle follow-up to the 1995 film Smoke, Auster's novel can be viewed as a contemporary updating of a regionalist literary mode Bramen dubs "urban picturesque" (157). In the late nineteenth century, the urban picturesque was characterized in novels such as William Dean Howells' A Hazard of New Fortunes (1890) by "a dramatic chasm between rich and poor combined with ethnic heterogeneity," and was hence the "aesthetic expression" of modernity's drive toward diversity (Bramen 156, 157).

12 If it was intended at that time to aestheticize and thus to defuse the immigrant threat by "linking New York cosmopolitanism with modern Americanism" (Bramen 158), the picturesque's function in texts such as Brooklyn Follies and, as we shall see, Kitty Burns Florey's Solos is different, if still somewhat reactive. Here, cosmopolitanism is neither alarmingly nor refreshingly new; it is the given fabric of Brooklyn society. Yet the Jamaican drag queens and Jewish grandmothers of Brooklyn Follies, the Polish artists of Solos, are all under threat from a malevolent outside force which, to risk employing an over-simplification the novels themselves fail to avoid, one might call "Manhattan." When Jonathan Lethem, in Motherless Brooklyn (1999), describes the clients of the Boerum Hill Inn as "Manhattanized," he is referring to a willed negation of past narratives, a melancholic spirit of newness and a homogenizing impulse spurred on by capital's desire to maximize a white, aspirant, bourgeois consumer market. This "dressed-up crowd at the inn" is "oblivious to the neighborhood's past or present reality" (Lethem 239). Similarly, it is no accident that Tab Hartwell, the villain of Solos, is associated with the metropolitan center. His run-down building on Crosby Street is "a rotten tooth in a mouthful of glossy caps," surrounded by luxury loft developments and is soon to become gentrified and indistinguishable from the rest (Florey 222).

Brooklyn, then, is "not New York" not only because "it retains a poignant sense of lost, prelapsarian identity" from before its assimilation into New York City in 1898 (Lopate), but also in the sense that its geographical proximity in no way presupposes any cultural or ethical propinquity with its more illustrious neighbor. Ostensibly, then, the starting point of contemporary Brooklyn regionalism is in opposition to the rapacious 
globalization symbolized by Manhattan. ${ }^{1}$ Indeed, in contrast to Manhattan's perceived shallow glamour, one might suggest, as Martin Tucker puts it, that

Brooklyn has played the fictional role of sheltering home and quasi-family, almost akin to those regional novels in which the central characters fall back on rural and small-town values to sustain them in their journeys outward (9).

What is remarkable initially is that the fears expressed by some Brooklyn writers over the bleaching of difference embodied by Manhattan are the same fears articulated by Henry James in The American Scene. Yet this eradication of alterity stems not from a desire to achieve an "American" identity, as it did in James' analysis, but from the global homogenization of economic and material desires under capitalism. Thus, Brooklyn fictions pit borough against center in order to discover where real community lies - in the maintenance of cultural, ethnic and socio-economic diversity, or in the sameness of bourgeois aspiration.

It is a brand of regionalism laden with ironies and tensions, however, as literary regionalism always has been. Tom Lutz goes further than Philip Joseph and asserts that, for a regionalist text even to be designated "literary," it must hold in precarious balance both "local and larger perspectives," and that for a text to come down emphatically on the side of local color is simply "to absolve its readers emotionally of accepting the very invitations to openness the form affords" (Lutz 192). To be literary is to engage in debate and not to resort to partiality or polemic. For Lutz, "[r]egionalist literary texts represent both sides of the major cultural debates of their time" and "dramatize the differences between and within classes, regions, sexes, and communities, but not with the intention of resolving them" (28). And, of course, it is frequently the very presence of a colonizing other which heightens awareness of regional identity in the first place, an irony noted by R. P. Draper (5). The danger for the Brooklyn regionalist is the retreat away from "cosmopolitan ideals of cultural inclusiveness" into an exclusive "urban elite fantasy" which narrows the focus almost to street level in a bid to retain an assumed ideal of authenticity (Lutz 25).

Both texts dealt with in the first section of this article - Kitty Burns Florey's Solos (2004) and Lynne Sharon Schwartz's Leaving Brooklyn (1990) - inhabit the predominantly domestic territory Philip Lopate notes has been typical of Brooklyn fiction since A Tree Grows in Brooklyn. It is also true that both deal with diversity, as well as touching on that prickly relationship between Brooklyn and Manhattan. However, they adopt different approaches to these themes, and treat them with unequal complexity. While one should hesitate to wield Lutz's term "subliterary," Florey's brand of regionalism, which comes in fact much closer to traditional definitions of the term, is less satisfactory because it subsists merely in the multiplication of quirky surface details. These are intended to evoke geographical and cultural specificity, but succeed only in creating a kind of taxonomy of local color which it is the protagonist's (and the author's) responsibility to "capture." In so doing, she risks becoming complicit in their disappearance by indulging in a form of - to borrow Fredric Jameson's phrase nostalgia for the present. Schwartz, on the other hand, avoids local detail, instead choosing to employ a central metaphor which actually dramatizes a multifaceted literary perspective. Such a "double vision" (Schwartz 5) reflects on the ever-present difficulty for the regionalist writer: does she write most "authentically" from "inside," "outside" or somewhere in between? In fact, Schwartz's text can be seen as an unmasking of the pretences and denials necessary to preserve a brittle sense of 
regional identity. Hers is less a regionalist novel than a deconstruction of more anodyne types of regionalism.

The borough represented in Solos, in keeping with classic Brooklyn novels such as Last Exit to Brooklyn and, more recently, Michael Stephens' The Brooklyn Book of the Dead (1994), is a place of immigration. Rather than Hispanic or second-generation, workingclass Irish immigrants, however, Florey's Williamsburg is populated by an eccentric set of artists, writers and dog lovers who have moved in from the suburbs or from other sections of the city for cheaper rents and a bohemian ambience:

Emily moved to the Williamsburg section of Brooklyn because that's where her friend Gene Rae Foster went to be with her boyfriend Kurt. It was only one subway stop across the river from Manhattan, and Gene Rae said the neighborhood was cheap and eccentric and full of artists and other interesting people. So it proved to be: Williamsburg was an urban wilderness of warehouses and factories, desolate streets, and crumbling, asphalt-fronted row houses you could see had been pretty once, with grand cornices and intricate iron fences, but were now ratty little boxes. The streets were almost bare of the delights of nature and the amenities of civilization. There was the occasional ailanthus, some sycamores, a few linden trees with their starry spring blossoms, and the vast but barren park. There were two delis, a dubious natural foods store, a Polish restaurant and a Polish bakery, a café near the subway entrance, two stores catering to the neighborhood pigeon flyers, and rumors that an art gallery was planning to open on North Ninth. Someday. You wouldn't know you were in New York City if the maddening, magnificent towers of Manhattan hadn't glittered just across the river (Florey 51-52, italics added).

This passage deserves closer scrutiny, for in many ways it is representative both of Florey's style and of the prejudices her style reflects. The narrator is a struggling photographer with a palindromic name, Emily Lime. As she describes the initial pull of Williamsburg, one might call the descriptive mode here (and elsewhere in the novel) "aggregative," in that the texture of the neighborhood is evoked largely through lists of loosely-associated elements - trees, shops and houses - from which the protagonist and reader are bound to construct something resembling a community. It is a technique also employed by Paul Auster in The Brooklyn Follies. ${ }^{2}$ Evidently, the presiding spirit is the Brooklyn Bard, Walt Whitman. Yet what is missing from the Florey extract is the avowedly federative impulse centered on the all-encompassing gaze of Whitman's plural "I." Instead, Florey offers an omniscient narrator who is, nonetheless, close to Emily's point of view.

Of course, this is in some ways a more accurate representation of the individual's relationship with the mass urban environment than Whitman's. For, as James KyungJin Lee makes clear, one cannot hope to perceive the whole of the city; objects appear and disappear rapidly and hence a Whitmanian "urban vision of American Romantic correspondence" is untenable (Lee 145). Fragmentation is the texture of one's urban experience, and it has two significant consequences. First, it persistently threatens alienation and dictates that one actively strive for a sense of community. Secondly, it encourages a concern with things, with the material and significatory elements which help to compose the environment. Such a concern, which drives the poetry of William Carlos Williams and Hart Crane, is laudable when it ensures attention to the material reality of a place and to how that reality shapes the collective consciousness.

20 But the attendant danger is that the concern with things becomes an obsession which leads not to a striving for society but rather to an atomization of the environment itself. Moreover, the need to locate significance in these things may inspire not a 
communal consciousness but an individual signifying consciousness which treats objects and other people as participants in a pre-devised symbolic system.

There is evidence of such an incorporative strategy in the narrator's/ Emily's thoughts on Williamsburg. It is revealed through a curious lacuna in the passage which betrays a distinctly colonial mindset. Emily's initial attraction to Williamsburg is its cheapness, as well as the "artists and other interesting people." Yet the following phrase, "So it proved to be," is followed by a lengthy description not of this supposed artistic community, but of the area's desolation, of its almost total lack of "civilization." Walt Whitman is careful to include poverty and degradation as part of the rich spectrum of human experience, but, notably, Florey's portrait is distinctly lacking in human content, apart from desultory mention of the "neighborhood pigeon flyers." What she presents is a wilderness space cleared for bohemian settlement, such that "So it proved to be" refers forward to a mythical "someday" when Emily and Gene Rae's predetermined vision of a culturally eclectic Williamsburg can be fulfilled. There is something familiar and mythical occurring here: a dream of a wild empty frontier space fit for colonization and civilization. The colon adumbrates the semantic elision in the text, reflecting the subjective vision of a cultural gap to be filled.

In the following quotation one can see what the wilderness comes to be filled with signs:

They pass the sushi place, the Mexican restaurant, the video store, the Syrian deli, the Polish bakery (whose BREAD sign Emily has photographed a dozen times), the new baby shop that has a pair of studded black leather booties in the window, and Marta's Beauty Salon, whose faded pink-and-green sign has probably not been retouched since 1966. They pass Mr. Suarez, with his Chihuahua, Eddie, in his pocket and a shopping basket full of soda cans. They pass the Pink Pony Thrift Shop with the WHAT GOES AROUND COMES AROUND sign on the door, and the used-book store and its new café, where they can smell the hot apple cider all the way out on the sidewalk. The smell seems exactly right, a perfect match to the brown leaves on the ground and the $\mathrm{V}$ of geese overhead and the signs in the drugstore window advertising Halloween candy (Florey 2-3).

This is very much a city of words, and Solos is a novel which, despite its apparent love of human society, operates systematically at the level of signifier. Emily is a photographer whose chief subject matter is signs: "it was words she wanted to photograph," we are told (52). In addition, her friend Marcus moved to Williamsburg on the strength of its palindromic zip code, 11211 (8). For Emily, the neighborhood is structured around an aggregate of familiar signs, and her fear is that these will eventually be replaced by signs epitomizing the globalizing, homogenizing tendency associated with Manhattan, an example of which are the "LUXURY LOFTS" signs surrounding Tab Hartwell's apartment block (221). What Emily fails to acknowledge, and the novel likewise, is that her framing of region is predicated on a wholly subjective myth-symbol complex which reduces it to a chosen caché of signs, and that the changes Emily so fears are themselves precipitated by the increasing affluence brought about by the arrival of boho immigrants.

It is no coincidence that the signs Emily admires, and many of the telling details she records (the shopping basket full of soda cans, the booties in the window) are connected with shopping. The aestheticization of consumption connoted here is not, in fact, a million miles from the converted, Manhattanized apartments in Emily's block which she finds "banal, boring, pretentious, untrue to the spirit of Brooklyn in general 
and Williamsburg in particular" (23). In other words, she unwittingly apes the Manhattan consumerist ethic she purports to resist. Florey here resorts to a mode one might label "consumer picturesque": diversity exists solely at the point of consumption, and the sometimes harsh economic realities of labor and production are elided. ${ }^{3}$ As Carrie Tirado Bramen notes, the facile celebration of ethnic food as metonym of cultural diversity is a recurring example of this elision, even in academic accounts of cosmopolitanism (Bramen 6-7). Emily's preoccupation with bakeries, cafés and soda cans is indicative of the same mystifying impulses. ${ }^{4}$

Moreover, repeated employment of the historical present tense combines at important reflective moments with the listing of signs, to produce the novel's characteristic wistful tone:

She sighs and logs off. Before the noon light bleaches everything out, she should get out on the streets, to photograph them for her new project, "Disappearing Brooklyn," the memorialization of the neighborhood before it dies. Death is on the way, she knows. There will come a day when the Polish meat markets and the Hispanic delis will be replaced by fast food outlets. When bookshops won't be called ksiegarnias, when trilingual signs like DRUGSTORE/FARMACIA/APTEKA will be taken down, and garish plastic DRUGMARTCO signs raised in their places (Florey 200).

Suffused with a sense of imminent obsolescence, and an entropic turn toward Manhattan-style sameness, the mood is one of nostalgia for the present. This prelapsarian present can only be believed in through strict denial of any previous "civilization" (as the first passage indicates). And it is a mood directly attributable to the taxonomic impulses of the characters - that is, the obsessive recording of things about-to-be-lost - and to the novel's style. It is as if the region itself must be under threat to exist at all, and that its imminent disappearance is the draw. But as one character is perceptive enough to point out, "'Things change, Em. They have to. And sometimes it's okay"' (268).

If, overall, it seems far from "okay" in Solos, it is because apparent authorial identification with the protagonist obstructs a more balanced perspective which might refuse unequivocally to come down on the side of local color. In the end, the novel fails to fulfill the promise offered by its palindromic title and the various palindromic names and figures within the narrative. Instead of seeing in regionalism a variety of mutually enriching pasts and presents, replacing nostalgia with a transitivity born of difference, the novel attempts to arrest change. The palindrome becomes a conservative figure: whichever way you look at it, the neighborhood must remain the same, just as one has mythologized it.

Once again, there is a wider discussion to be had in the light of $9 / 11$, a discussion which regrettably must be reserved for a later date. Suffice to say for now that the attractions of this nostalgic retreat are obvious. In the face of malevolent grand narratives, retreat into taxonomies of local color is easier and preferable to a head-on confrontation with the bigger issues. Ironically, the reduction of the region into signifying details is in its own way a destructive act. It is akin to looking too closely at a canvas, deliberately aiming to miss the whole picture. As Theo Perowne says in another post 9/11 novel, Ian McEwan's Saturday, "the bigger you think, the crappier it looks" (34). Solos thinks small, ${ }^{5}$ and yet for a contemporary reader it is haunted by the specter of bigger questions, just as Brooklyn is still overlooked by "the maddening, magnificent towers of Manhattan" (52). ${ }^{6}$ 

out that it lacks the necessary self-consciousness of the fact that region is to a large extent an internal construct, even if determined by the material environment. Lynne Sharon Schwartz's Leaving Brooklyn displays a much higher degree of reflexivity, and in so doing offers a radically different view of urban regionalism. It is not a regionalist novel in any traditional sense, but more a meditation on how region has traditionally been imagined, leading to a possible alternative. "The Brooklyn of my story is a state of mind or perception," claims Audrey, the narrator, or

the shadow field on which my good and bad eyes staged their struggle. [...] It moves from place to place wherever opposing visions struggle, but unlike a shadow it never changes with the light. One can only live in it or flee (Schwartz 16).

The key phrase here is "opposing visions." Although it is ostensibly built around binary oppositions, most significantly that between the redacting self and "that girl I was" (7), the logic of the novel's structure pivots on a highly resonant ocular metaphor which dismantles any simple oppositions. Ultimately this includes, one should stress, the opposition between living and flight suggested above. For Audrey, who has had an injury to her right eye since being dropped at birth, realizes that "common binary vision" - that is, fully functioning sight - is not, as the term suggests, anything to do with duality but in fact with the operation of two eyes in tandem to provide a perception of the world "of a piece, with a seamless skin like the skin of a sausage holding things together" (4). In contrast, her right eye's fragmented gaze offers a unique view of the tensions and distortions lurking behind this "seamless skin." Leaving Brooklyn is therefore a coming-of-age narrative which, while pivoting on sexual experience, describes the blossoming of a specifically literary awareness. Through this awareness, Schwartz is able to tackle both the regional and the global, and to offer a critique of the kind of domesticated Brooklyn fiction exemplified by A Tree Grows in Brooklyn and latterly Solos. She illustrates that Brooklyn is indeed "a state of mind or perception" (16). And, in almost casually stating that "[i]t could as readily be called Cleveland or Rouen or Johannesburg" (16), Audrey, via Schwartz, makes it clear that Brooklyn is a representative (or indeed a self-allegorizing) place. Thus the novel is less about the problems of leaving this specific borough than about the mentality of urban regionalism itself, using Brooklyn as a model.

31 Whereas Solos offers a bohemian fantasy world mostly narrated in the historical present to give an illusion of timeless qualities, Leaving Brooklyn is keen to historicize both the action of the plot and, importantly, the collective fabrication of a parochial mindset. This is "Brooklyn on the eve of war, a locus of customs and mythologies as arbitrary and rooted as in the Trobriand Islands or the great Aztec city of Teotihuacán [...]" (1). It is an urban area which, in a time of conflict, affects a down-home regionalism,

a presumption of state-of-nature innocence, an imaginative amnesia, and a disregard of evidence such as photographs of skeletal figures in striped pyjamas clawing at barbed wire [...] (13).

(One is reminded of Solos' airbrushing out of 9/11's consequences.) Most importantly, this image of region as nurturing safe haven, remote from the world at large, is quite self-conscious and deliberate. "Whatever depth perception there was in Brooklyn," Audrey observes, "was flattened by the collective will" (15). Concerned to preserve the regionalist idyll, the citizens of Brooklyn admit of "no gulf between image and reality" (13). 

as A Tree Grows in Brooklyn, she goes further by explaining that in a supposedly postmodern world in which '“image' has detached from reality to acquire independent life" (13), such fictions are untenable. She is right: one could also argue that the contemporary world offers a volatile admixture of, to use Simon Malpas' expression, resurgent "grand narrative politics" (41) and an ever-increasing multitude of micronarratives and subjectivities. This is, as we have seen, a point Solos chooses not to acknowledge.

In such a world there is a need for a sophisticated treatment of regionalism like Schwartz's, and it is young Audrey's deviant eye which opens up the possibility of such a treatment for "this I who makes up stories," the adult, writing Audrey (145). Left alone, the "good" left eye would settle for the assumed parochial innocence of Brooklyn, "the principle of cohesiveness" at work. The right eye, however, allows Audrey secret insight into "the great world," where "a naughty, mercurial principle of divisiveness, entropy and unsettling" operates (37). vision:

The eye was of scant use in seeing what had to be seen in daily life in Brooklyn. It was made for another sort of vision. By legal standards it was a blind eye, yet it did see in its idiosyncratic way - shapes and colors and motion, all in their true configurations except all turned to fuzz. Its world was a Seurat painting, with the bonds hooking the molecules all severed, so that no object really cohered; the separate atoms were lined up next to one another, their union voluntary, not fated. This made the world, through my right eye, a tenuous place where the common, reasonable laws of physics did not apply, where a piece of face or the leg of a table or frame of a window might at any moment break off and drift away. I could tease and tempt the world, squinting my left eye shut and watching things disintegrate, and when I was alone my delight was to play with the visible world this way, breaking it down and putting it back together. I had secret vision and knowledge of the components of things, of the volatile nature of things before they congeal, of the tenuousness and vulnerability of all things, unknown to those with common binary vision who saw the world of a piece, with a seamless skin like the skin of a sausage holding things together. My right eye removed the skin of the visible world (Schwartz 4).

Atomization is the eye's chief function, the disintegration of the seamless version of the world to which her parents' Brooklyn aspires, but the important point here, and the quality which differentiates the text from Solos, is that Audrey is able to break down and re-assemble the world by means of squinting or closing one or other eye. In other words, the fractured and the seamless perspectives are held together in exquisite tension, just as within the passage there is a mix of simple sentences and complex sentences broken into many sub-clauses. Most significant, for this argument, is Audrey's recognition that the atoms comprising the world are held together by "voluntary, not fated" union. This is, then, an anti-essentialist standpoint - there is nothing given about Brooklyn's character (even its diversity), despite her parents' generation's insistence to the contrary.

For the young Audrey, Manhattan possesses all the attractive qualities woefully underrepresented by the older generation's parochial Brooklyn. Manhattan is the place where "the big men" can be found (30); it is "mythic," "jewelled," and "impossibly sophisticated" (62). In a reversal of Solos' regional ethic, Manhattan offers the infinite 
variety and the depth young Audrey is constantly seeking. Audrey, bedazzled by its cosmopolitan style, is not prepared to exercise the same deconstructive gifts here that she applies to Brooklyn. However, when it becomes clear that the eye doctor she is sent to see by her mother is sexually attracted to her, she is forced to open her mind to

untenable thoughts, to a universe where human nature was not as Brooklyn conspired to portray it, progressing towards ever more expansive plateaus of decency and tolerance, but rather where people were driven chaotically by impulses, everyone wanting something from everyone else and staggering about to get it (67-68).

In short, the visions of the seamlessly fabricated, ordered world and the entropic world compete for supremacy just as much here as they do in Brooklyn.

Through her subsequent affair with the eye doctor, Audrey learns of a tactile reality beyond the life of the mind (74), and of the "monotony" which inevitably follows the excitement of desire (91). Most of all, she learns the true value of her rogue eye. Rather than simply being a means of carrying her momentarily beyond the confines of Brooklyn and "down those broader paths" (30), it represents the gift of an incisively literary or critical standpoint. When the writing Audrey declares, as the affair draws to an awkward close, that "[s] he was me, at that moment. She already knew what I know" (114), it is a recognition that a generic distinction is no longer acceptable between "Brooklyn" and "the world," and indeed between "the world as it is" and "the world as people wish to see it." After all, the eye itself embodies the contradictions: it can be both a "wayward eye" (30), constantly seeking adventure beyond the domestic, and a "lazy" eye, "an incarnation of the body's dearest tropism, the leaning towards more somnolent forms of life" (65).

Schwartz appears, then, to present what Tom Lutz calls the "dynamic of alternating cultural visions structuring a reading that exceeds them all [which] occurs in the great regionalist writing." He continues:

Regionalist texts represent the arguments alive in the culture about city and country, nature and culture, center and periphery, tradition and modernity, high and low, masculinity and femininity, the costs and benefits of progress, and any number of other issues; but instead of resolving these debates, they oscillate between the sides, producing, finally, a complex symphony of cultural voices and positions whose only resolution lies in the reader-writer compact to survey the fullness of the scene (Lutz 31).

41 In other words, the writer and the reader have a privileged overview of the competing visions portrayed in the regionalist text and are therefore in a position to make informed judgments. This, one could argue, is an inflated and inaccurate ideal of their roles, a point returned to at the end of the article. Suffice to say for now that, on the surface, the mature Audrey appears to believe in her ability "to survey the fullness of the scene," through realizing that "there [is] life in Brooklyn" (144) just as there are denial, secrets and monotony in Manhattan.

However, Schwartz does not even allow the reader to settle unquestioningly for a split between the naïve, Brooklyn Audrey and the wise, literary adult Audrey who informs us that she did eventually leave the borough (145). The last page takes the form of a disquisition on memory, in which adult Audrey muses on the concatenating tendency of her literary vision: 
Perhaps I haven't succeeded in finding the girl I was, but only in fabricating the girl I might have been, would have liked to be, looking backwards from the woman I have become (146).

In this sense, the generic boundaries of the coming-of-age narrative itself are blurred: the more or less neat transition from immaturity in the regions to full knowledge in the big world outside is shown to be retroactively constructed. Finally, Audrey reminds us that the storytelling impulse represents the final combination of the fragmentary and the coherent visions:

By this time the border between seeing straight on and seeing round the corner of solid objects, between the world as smooth and coherent and the world as dissociated skinless particles, is thoroughly blurred. No longer a case of double vision, but of two separate eyes whose separate visions - what happened and what might have happened - come together in what we call the past, which we see with hindsight (Schwartz 146).

44 The blurring described here is, ironically, essential for a clarity of vision which can accommodate the merging of fact and fiction, real and imagined, in the portrayal of autobiography and urban region. "Brooklyn" has therefore become simultaneously a real place, a testing ground for an ambiguous literary perspective, and a model of how memory works.

45 For Kitty Burns Florey, regionalism consists in the fossilization of signifying details, the fear of change over time. For Schwartz, ultimately, it is an ongoing process, something worked through persistently in the act of writing, and interminable. As Audrey says: "I left Brooklyn. I leave still, every moment. For no matter how much I leave, it doesn't leave me" (145).

6 This may appear to be no more than a sophisticated articulation of the adage, "You can take the girl out of Brooklyn [...]," but the ceaseless interplay of staying and leaving it describes is central to the argument. Time and again in contemporary Brooklyn fictions one sees this model of urban region-as-process rehearsed. In each instance, the process consists of arrivals and departures - continual movement between local and global perspectives, between urban region as material reality and imagined community, between pasts and presents, and between region as geographical specificity and heterotopic everyplace.

The Brooklyn of Michael Stephens' The Brooklyn Book of the Dead, for example, is resistant to the family legends of its main characters, the Cooles, a large and unruly Brooklyn Irish family. It rejects the "myth of geography and forebears" (72). Despite "lending itself more to the imagination than facts" (23), like Audrey's Brooklyn, it is too bound up in historical and demographic change to allow itself to be defined by one family's myths. As the Coole brothers and sisters return to "East New York" for the funeral of their father (37), the "flinty and cold-eyed nostalgia" identified by Jonathan Lethem usurps any attempt at idealization of anecdotal family history. After all, it is impossible to feel the warm glow of nostalgia for a place that never was primeval or based on rootedness rather than transition. As the narrator puts it, "[e]ven before the '77 riots, that notion of getting out pervaded anyone who was in here" (93). The preposition "in" connotes incarceration in both the material reality of squalid tenements and treeless streets, and the futile dream of mapping the area ancestrally through "land and blood" (Joseph 10). Pessimistic about the borough's potential to bring unity or understanding, The Brooklyn Book of the Dead reads like an anti-regionalist novel. 

takes the idea of region-as-process even further and travels further even than Schwartz from the geographical specificities and local color of Florey's Brooklyn. It should be clear by now that the preoccupation here is not with regionalist literature in any traditional sense, but more with the differing uses to which Brooklyn as a real or imagined space is put in contemporary texts. On the surface, Lethem's novel (like Schwartz's) certainly carries few of the hallmarks of classic American regionalism. For a start, it is set on a distant planet inhabited by the mysterious Archbuilders, a race of aliens made of "flesh and fur and shell and frond," with hair resembling "a bungle of calla lilies" and a habit of adopting bizarre yet strangely poetic English collocations for names, such as "Hiding Kneel" (61). Yet, in chronicling the arrival of human settlers on the planet, and their subsequent relationships with the Archbuilders, the novel does reflect an enduring regionalist theme: the effect on a community of the arrival of outsiders. In this case, the outsiders are the Marsh family, evacuees from a blighted Planet Earth of the future. And like A Tree Grows in Brooklyn, it is a coming-of-age narrative, a story of how a young girl achieves adulthood through hardship and calls upon her community for support. Here, however, the community is not yet established; it is on the brink of foundation, at a stage of frontier encounter.

Girl in Landscape is a Brooklyn fiction, though one in the abstract, in which the borough undergoes a radical transposition. Here, past and future, earth and space, reality and fantasy, all collapse in a genre-twisting meditation on the reconciliation of inner impulses and the formation of a community from melancholic fragments. In this novel, Brooklyn is "not New York" and not of this earth. Yet in interview, Lethem has admitted that after the outlandish fictions of Gun, With Occasional Music, Amnesia Moon and As She Climbed Across the Table, his fourth novel represents a sort of homecoming and a confrontation with his past:

For years, I was overwhelmed by Brooklyn [...]. The richness of my own upbringing was too much for me to contend with, either in my life or my writing, and so I was in a kind of flirtation. When you see me going back in the first couple of chapters of Girl in Landscape, you're seeing me daring myself to open that box and really let it come (Zeitchik 37).

In these opening chapters, we meet the Marsh family who, after the father's loss of an election and of his political reputation, are set to emigrate to the Planet of the Archbuilders. Before leaving, they embark on one last family outing to the beach, travelling by subway through the shattered urban topography and under the blasted, DeLillo-esque skies of a vaguely futuristic Brooklyn. Global warming has reached its logical conclusion. The sun is now "the enemy: horrible, impossible, unseeable" (9).

Pella, the teenage protagonist, is nonetheless reluctant to leave Brooklyn, and her fears are compounded by the sudden death from a brain tumor of her mother, Caitlin. Given that Lethem's mother died in 1978 when he was fourteen, and that the absent mother theme is reprised in both Motherless Brooklyn and The Fortress of Solitude, one has to regard Caitlin's departure as a pivotal moment not just in the narrative of Girl in Landscape but in Lethem's writing career. It is the first direct attempt to "open the box" of his autobiography. For Lethem, as for Pella, Brooklyn is inextricably connected to the loss of the mother. However, Lethem's technique here is to relocate and re-imagine the maternal Brooklyn in the Planet of the Archbuilders, a surreal and melancholic landscape littered with ancient ruins from former Archbuilder civilizations. As fragmented as the Brooklyn left behind, this is a "landscape of remembrance" (49) not 
just because the ruins are testimony to the ambitious creativity of previous generations, but also because Pella envisages it as a maternal landscape. "Caitlin had left but was still here," we are informed, "[h]er voice hung over this landscape" $(49,48)$.

As Carl Abbott observes, Girl in Landscape (along with sci-fi novels such as Ray Bradbury's The Martian Chronicles) is a homesteading novel which uses archetypal frontier narratives to dramatize concerns about the future. More specifically, it deals with the evolution of community through the settlement of disparate individuals. What distinguishes it from more traditional frontier narratives, however, is not simply the alien environment, but the way in which the alien landscape speaks simultaneously of the mourned past and of the optative future, as well as linking the personal and collective concerns.

For Pella, the development of the new community is co-terminous with the traditional elements of the coming-of-age narrative (in particular the rejection of paternal authority), and with her personal project to externalize the mourning of her mother in the landscape. These symbolic connections are confirmed by her culminating verbal rejection:

"He's nothing without my mother." The words snuck out of her like a thread between her lips, a betraying filament that stretched back to Brooklyn, to Pineapple Street (240).

For the first time, the symbolic linking of her former home and the alien landscape is explicitly acknowledged. Pella's aim is thus to become "a feature of the landscape" (173), but this is not a form of retreat. Rather, it signals her awareness of what the landscape represents: a chance to reassemble the scattered fragments of memory in the establishment of a new community. The town of "Caitlin" which she founds at the close of the novel is her maternal Brooklyn re-imagined, the culmination of the mourning process (279).

While Pella might appear to fabricate a myth-symbol complex every bit as incorporative and solipsistic as Emily Lime's in Solos, or the Cooles' in The Brooklyn Book of the Dead, there is in fact a fundamental and redeeming difference. Whereas Solos' nostalgia for the present requires, as we have seen, a denial of what came before (thus locating it in a mythic tradition which includes Thomas Cole's Essay on American Scenery and Frederick Jackson Turner's frontier thesis), Pella recognizes the importance of the indigenous inhabitants, the Archbuilders, in the development of the new community. In an obvious allegory of the encounter with Native Americans (and less obviously of contemporary immigration issues), Girl in Landscape envisages the new Brooklyn as a process of continual meetings with absolute otherness, a transgression of the boundaries of the self. Pella ultimately distinguishes herself ethically, and truly comes of age, when she realizes this:

None of what happened was really about Archbuilders, Pella decided [...]. It was still all about the humans, what they saw when they looked at the Archbuilders [...]. Maybe now they would meet them. Maybe the Archbuilders would buy the bread. (279)

Breaking free of the solipsistic gaze frees the self from a colonial or parochial settler mentality (the kind evinced in Solos) and allows a conception of regional community which, in this context, not only combines the local with the global, but transcends worlds. ${ }^{7}$ 

nuanced portrayals of a region both specific and representative, but also the sense that all three texts are allegories of reading. Audrey's coming-of-age, as we have seen, is commensurate with the emergence of her literary perspective. In the process of reading about it, we are in effect taught how to read Brooklyn, to exercise our deviant eyes and disassemble the skin holding together a belief in primeval regional values. Proceeding from the death of the author (the father), The Brooklyn Book of the Dead presents us with a multi-vocal, fragmented structure, shifting chronologically and in space from Brooklyn to the New Jersey suburbs where a number of the Coole siblings now live. Our reading thus participates in a regionalism not ahistorical, as in Solos, but rhizomic, formed not by patrilinearity, but through ceaseless negotiations across history and between center and suburb, borough and metropolis.

Entering the landscapes of Girl in Landscape as a reader is by no means a wholly comforting experience. Indeed, Pella's isolation throughout the novel stems largely from the epistemological and ethical supplement she is afforded as the most perceptive reader of events. It is she who has the "lonely knowledge" that the whole truth is never available (66), but at the same time she witnesses, during a series of out-of-body experiences brought about by exposure to the planet's native viruses, a number of secrets. These include her father's affair with the biologist, Diana Eastling (166) and the artist Hugh Merrow's sexual relationship with an Archbuilder (121-23). In bearing witness to these events "[i]t was Pella who was most alone in the end, knowing all she knew" (169). Yet her transition from adolescence to adulthood, somewhat like Audrey's, combines an awareness that reading is partly the uncovering of secrets with an understanding that, in the end, the textual landscape will always retain a certain "clandestinity" amenable to ethical reading (Newton 246). That is, any attempt fully to "know," or to take in "the fullness of the scene," becomes an incorporative strategy like Emily Lime's, a desire to possess.

Crucial to this understanding, once again, are the Archbuilders: their irreducible difference, which "burn[s] a hole in the world, change[s] it utterly" (62), refuses incorporation. The ethical challenge they issue is symbolized by the figure of the arch itself: reading is an individual or solitary act, but to enter the landscape of "crumbled arches [...], [f]allen bridges, incomplete towers, demolished pillars" (48) constitutes an ethical conjunction to "explore the boundaries" (125), to become a member of a wider community founded on true difference, not superficial diversity. An arch, after all, is something with the potential to connect.

Clearly, Lethem sees the real Brooklyn in similar terms to the Archbuilders' landscape:

It's a place where the renovations that are so characteristic of American life never quite work. It's a place where the past and memory are lying around in chunks even after they've been displaced (Zeitchik 37).

61 Viewed in this way, it is very much a "broken land" of mourning. ${ }^{8}$ As this article has suggested, Pella's success, and Girl in Landscape's, lies in taking the process of private mourning - for Caitlin, and for the author's own mother - and in forging a community from it in the foundation of "Caitlin." Distinct from the pre-lapsarian cravings of nostalgia, or the hagiography of ancestors that is the weakness both of the Coole brothers and of the Archbuilders (GL 241), such mourning is the recognition of the inseparability of past experience from the communal present and future. Most importantly, it lies at the heart of all reading. Every reading experience combines 
remembrance of stories which have passed with a series of encounters, negotiations and inventions of new relationships.

Therefore, Pella's translocated maternal Brooklyn is not an atavistic utopia, but rather a regional space representative of what readers do: the bringing of internalized fragments of memory and experience to bear on the ethical encounter with the alien (yet strangely familiar) landscapes of the text. In light of Lethem's vision, and indeed Lynne Sharon Schwartz's, one might be tempted to modify the traditional conception of the novel as a created world: in continually staging negotiations between the reader's personal perspective and its inherently dialogic, transitive nature, the novel functions something like a region itself. In the end, contrary to Tom Lutz's assertion, the most successful Brooklyn fictions are those which deliberately disallow protagonists and readers access to "the fullness of the scene." Solos thinks small in order to hold on to a personal fantasy of diversity which is nonetheless complete within in its own solipsistic confines; thus, for all its nostalgia for community, it represents the kind of secession from connection described by Zygmunt Bauman. Leaving Brooklyn and Girl in Landscape, in contrast, use abstracted Brooklyns - "broken lands" - as allegories of fragmented reading. They demonstrate that the individual needs others to complete the scene, and that the resultant community is an endless series of what Martin Buber calls "relational incident[s]" (46). Those Brooklyn fictions which actually stray away from local color, from signifying details, and from facile comparisons with Manhattan, dramatize the ethical endeavor involved in constructing regions and communities, and involve the reader more directly in that endeavor. In so doing, they reconfigure Brooklyn itself as an ethical space, not simply Manhattan's friendlier neighbor.

Works Cited

Abbott, Carl. "Homesteading on the Extraterrestrial Frontier." Science Fiction Studies 32.2 (July 2005): 240-64.

Auster, Paul. The Brooklyn Follies. New York: Henry Holt and

Company, 2006.

- - - 3 Films: Smoke, Blue in the Face, Lulu on the Bridge. New York: Picador, 2003.

Bauman, Zygmunt. Community: Seeking Safety in an Insecure World. Cambridge: Polity, 2001.

Bradbury, Ray. The Martian Chronicles. New York: Bantam Books, 1950.

Bramen, Carrie Tirado. The Uses of Variety: Modern Americanism and the Quest for National Distinctiveness. Cambridge, MA: Harvard UP, 2000.

Buber, Martin. I and Thou. 1937. London: Continuum, 2004.

Cole, Thomas. "Essay on American Scenery." American Monthly Magazine 1 (Jan. 1836): $1-12$.

Draper, R. P. (ed.). The Literature of Region and Nation. Basingstoke: Macmillan, 1989.

Florey, Kitty Burns. Solos. New York: Berkley Books, 2004.

James, Henry. The American Scene. 1907. London: Penguin, 1994.

Jameson, Fredric. "Cognitive Mapping." Marxism and the Interpretation of Culture. Urbana and Chicago: $U$ of Illinois P, 1988. 347-58.

- - . . Postmodernism: Or, the Cultural Logic of Late Capitalism. London: Verso, 1991. 
Joseph, Philip. American Literary Regionalism in a Global Age. Baton Rouge: Louisiana State UP, 2007.

Kowalewski, Michael. "Contemporary Regionalism." A Companion to the Regional Literatures of America. Ed. Charles L. Crow. Malden, MA: Blackwell, 2003. 7-24.

Kushner, Seth and Anthony LaSala. The Brooklynites. Brooklyn: Powerhouse Books, 2007.

Lapote, Phillip. “Destination Brooklyn.” Salon. 3 July 2006.

<http://www.salon.com/books/literary_guide/2006/07/03/brooklyn/>.

Lee, James Kyung-Jin. "The City as Region." A Companion to the Regional Literatures of America. Ed. Charles L. Crow. Malden, MA: Blackwell, 2003. 137-53.

Lethem, Jonathan. Girl in Landscape. London: Faber and Faber, 2005.

- - . Motherless Brooklyn. London: Faber and Faber, 2004.

Levinas, Emmanuel. Totality and Infinity. Trans. Alphonso Lingis. Pittsburgh: Duquesne UP, 1969.

Lutz, Tom. Cosmopolitan Vistas: American Regionalism and Literary Value. Ithaca and London: Cornell UP, 2004.

Malpas, Simon. The Postmodern. Abingdon: Routledge, 2005.

McEwan, Ian. Saturday. London: Vintage, 2006.

Newton, Adam Zachary. Narrative Ethics. Cambridge, MA: Harvard UP, 1997.

Schwartz, Lynne Sharon. Leaving Brooklyn. London: Mandarin, 1990.

Sohn, Amy. My Old Man. New York: Simon and Schuster, 2004.

Stephens, Michael. The Brooklyn Book of the Dead. Normal, IL: Dalkey Archive P, 1994.

Tucker, Martin. «What Is This Thing Called Brooklyn?» The World of Brooklyn : An Appreciation by Brooklyn Writers. Ed. Martin Tucker. Brookville, NY : Confrontation Magazine P of Long Island U, 1988. 7-11.

Varvogli, Aliki. «Thinking Small Across the Atlantic: Ian McEwan's Saturday and Jay McInerney's The Good Life. » Symbiosis 11.2 (Oct. 2007) : 47-59.

Zeitchik, Steven. "A Brooklyn of the Soul.» Interview with Jonathan Lethem. Publishers Weekly. 15 September 2003.37.38.

\section{NOTES}

1. This is not to say that one should endorse such a view, only that setting up such a dichotomy is convenient for the purpose of many Brooklyn authors. One could argue that Manhattan itself felt the full force of global narratives on 9/11, and therefore the comparison is largely a tactless or unfair one in reality.

2. For example: "Now, as we took our walks up and down Seventh Avenue, passing the dry cleaner, the grocery store, the bakery, the beauty parlor, the newsstand, the coffee shop, she was assaulted by a plethora of different tongues. She heard Spanish and 
Korean. Russian and Chinese, Arabic and Greek. Japanese, German and French [...]" (Auster 229).

3. In Amy Sohn's My Old Man (2004), the consumer picturesque is reconfigured as what one might call "the sexual picturesque." Here, diversity is expressed through the sexual peccadilloes of Cobble Hill's resident nymphomaniac Liz Kaminsky and the racial characteristics of her many partners. Her rapacious sexuality is itself a type of consumerism, expressed in generalising terms: "She enjoyed having her own asshole violated, and said the reason she loved black guys was because they were more open to doing so" (43). Like many other Brooklyn novels, the underlying fear is of gentrification and homogenisation. In My Old Man, the narrator moves to Cobble Hill just as "the honkeys started coming out to play" and "the Puerto Ricans had long ago sold their religious article shops and hightailed it back to the island" $(13,14)$. The sexual picturesque is a way of holding on to local color on an individualistic level, while largely ignoring the larger economic and demographic issues.

4. The Brooklynites provides yet more evidence. It ends with "a simple list of some of the food and beverages consumed on this journey," including sushi, Thai cuisine, pizza, falafel and turkey sandwiches. This is a taxonomy clearly designed to stand as a metonym of cultural and ethnic diversity. The consumer picturesque is in fact a form of, "cognitive mapping," to employ Fredric Jameson's influential term, though it is a form which makes no attempt to resist the commodification of experience, but rather provides the individual with a sense of regional and global position explicitly through commodity consumption.

5. I am indebted to Aliki Varvogli for the idea of "thinking small." See her article “Thinking Small Across the Atlantic: Ian McEwan's Saturday and Jay McInerney's The Good Life" in Symbiosis 11.2 (Oct. 2007): 47-59.

6. Paul Auster's Brooklyn Follies works slightly differently. Rather than resolutely thinking small, it saves the intrusion of $9 / 11$ for the very last page. That way, the action of the novel, the accumulation of small lives of ordinary people, acts as a retroactive preparation for and defence against the tragedy.

7. Although a detailed philosophical analysis is beyond the scope of this article, it is worth noting that Pella's recognition of the Archbuilders has a distinctly Levinasian tincture. Their alien otherness ruptures the securities of human conception. Pella, however, is able to move beyond a view of the Archbuilders as generic mass to an appreciation of their singularity through language. The key moment comes toward the end of the novel, when Pella goes looking for the imprisoned Archbuilder, Hiding Kneel: “'Hiding Kneel?' she whispered. The words were odd in her mouth. She'd never called an Archbuilder by its name. She said the name again, a bit louder" (251).

Through the simple utterance of the name, Pella feels the strangeness of the Other, the strangeness of her self, and learns that the world is not hers alone. There are strong parallels here with Levinas' description of the encounter with the Other in Totality and Infinity.

8. Brooklyn's name derives from the original Dutch settlement Breukelen, meaning "broken land." 


\section{ABSTRACTS}

The article analyzes the depiction of Brooklyn as an urban region in a number of recent American novels, including Lynne Sharon Schwartz's Leaving Brooklyn and Kitty Burns Florey's Solos. It argues that Brooklyn is frequently defined in opposition to Manhattan: the former being viewed as the epitome of American ideals of community-in-diversity, the latter as homogenizing, globalizing and obsessed with newness. In a time when regions and communities are frequently regarded as under threat from, amongst other things, globalization and terrorism, it is interesting to examine whether the ideals of diversity and community associated with Brooklyn are based on nostalgic, mythic notions of land and family or are in fact based on superficial signifiers of diversity and a range of consumer choices. The article goes on to argue that the complex interactions between the regional and the global in these novels can be seen as analogous to processes of reading regional texts themselves.

\section{INDEX}

Keywords: Regionalism, Joseph, Brooklyn, community, diversity, picturesque, consumerism, local color, reading, Auster, Paul, Abbott, Carl, Bauman, Zygmunt, Bramen, Carrie Tirado, Buber, Martin, Cole, Thomas, Crane, Hart, Florey, Kitty Burns, Fox, Paula, Howells, William Dean, James, Henry, Jameson, Fredric, Philip, Kushner, Seth, Lapote, Phillip, LaSala, Anthony, Lee, James Kyung-Jin, Lethem, Jonathan, Levinas, Emmanuel, Lutz, Tom, Malpas, Simon, McEwan, Ian, Newton, Adam Zachary, Schwartz, Lynne Sharon, Selby Jr., Hubert, Smith, Betty, Sohn, Amy, Stephens, Michael, Tucker, Turner, Frederick Jackson, Whitman, Walt, Williams, William Carlos

\section{AUTHOR}

\section{JAMES PEACOCK}

James Peacock, Keele University 